\title{
PORTUGUESE GRAMMAR INSTRUCTION: VIEWS OF HERITAGE AND FOREIGN LANGUAGE LEARNERS
}

\author{
O ENSINO GRAMATICAL EM PORTUGUESS: PERSPECTIVAS DE APRENDIZES DE \\ LINGUA ESTRANGEIRA E DE LINGUA DE HERANÇA
}

\begin{abstract}
Gláucia Silva ${ }^{94}$
ABSTRACT: Research on learner perception has shown that foreign language learners consider formal grammar study quite important (SCHULZ, 1996). However, we know little about perceptions and beliefs of heritage language learners in what relates to grammar instruction. In a qualitative study on heritage language instruction at the college level, Schwarzer and Petrón (2005) do include the opinions of their participants on grammar instruction: that formal grammar instruction, as done in foreign language classes, was not useful for them. In fact, it is now accepted that heritage language instruction needs to be different from foreign language instruction (e.g., BEAUDRIE; DUCAR; POTOWSKI, 2014; PARODI, 2008). Nevertheless, most heritage language learners of Portuguese at the university level take foreign language classes, even if a track designed specifically for them is available. Given this scenario, this paper discusses 1) whether heritage and foreign language learners of Portuguese prefer formal or integrated/contextualized grammar instruction, and 2) whether they believe explicit grammar instruction helps their linguistic development in Portuguese. The methodology consisted of a survey among college students matriculated in Portuguese language classes in a U.S. university. Results suggest that heritage learners tend to prefer integrated/contextualized grammar instruction, whereas the foreign lanague group does not appear to have a clear preference. However, both groups of learners see value in explicit grammar instruction, which does not necessarily contrast with contextualized instruction (ELLIS, 21016). The paper also includes a discussion of pedagogical implications based on the findings presented.
\end{abstract}

Keywords: Heritage language; foreign language; learners' views; grammar instruction.

RESUMO: A pesquisa sobre a percepção de aprendizes revela que aprendizes de língua estrangeira consideram o estudo formal da gramática muito importante (SCHULZ, 1996). No entanto, sabe-se pouco a respeito das visões e crenças de aprendizes de língua de herança no nível universitário no que toca a instrução gramatical. Em um estudo qualitatito sobre instrução em língua de herança no nível universitário, Schwarzer e Petrón (2005) incluem opiniões dos participantes a respeito da instrução gramatical: para eles, a instrução gramatical formal, tal como em aulas de língua estrangeira, não era útil. De fato, atualmente aceita-se que a instrução voltada para língua de herança deve ser distinta daquela aplicada em contextos de língua estrangeira (p. ex., BEAUDRIE; DUCAR; POTOWSKI, 2014; PARODI, 2008). Mesmo assim, muitos aprendizes de português língua de herança no nível universitário matriculamse em aulas de português língua estrangeira, mesmo quando se oferecem cursos específicos para esses aprendizes. Assim, este artigo discute 1) se os aprendizes de português língua de herança e língua estrangeira preferem instrução gramatical formal ou contextualizada/integrada, e 2) se eles creem que a instrução gramatical explícita auxilia o seu desenvolvimento linguístico em português. Os resultados sugerem que os aprendizes de herança costumam preferir a instrução contextualizada, enquanto os aprendizes de língua estrangeira não declararam uma preferência clara. Porém, ambos os grupos de aprendizes valorizam a instrução gramatical explícita, que não se contrasta necessariamente à instrução contextualizada (ELLIS, 2016). O artigo inclui também uma discussão de implicações pedagógicas com base nos resultados apresentados.

Palavras-chave: Língua de herança; língua estrangeira; opiniões dos aprendizes; instrução gramatical.

\section{Introduction}

Heritage and foreign language learners exhibit different instructional needs, as has been argued since at least the late 1970s (CARREIRA, 2016; CUMMINS, 1979, 1983; FRIEDMAN; KAGAN, 2008; LYNCH, 2003; MONTRUL, 2016; PEIRCE, 2018; RANDOLPH, 2017; VALDÉS; LOZANO; GARCÍA-MOYA, 1981; among others). These differences are related to their linguistic experience: while a heritage language (HL) is learned in a naturalistic environment

\footnotetext{
${ }^{94}$ Ph.D. in Hispanic Linguistics from the University of Iowa. Professor in the Department of Portuguese at the University of Massachusetts Dartmouth-USA.
} 
(generally the family home), a foreign language (FL) is learned in the classroom and/or in study abroad experiences (MONTRUL, 2016). Valdés (2001, p. 38) contends that heritage language learners (henceforth, HLLs) are to some degree bilingual in that language and the majority language. Foreign language learners (henceforth, FLLs), on the other hand, tend to have had no previous experience with the language in question before taking a class or traveling abroad. These distinct experiences imply differences in how these two groups approach language learning.

Researchers have argued that, among other dissimilarities, HLLs and FLLs approach grammatical features differently. Parodi $(2008,211)$ maintains that FLLs use grammar to access the language, while HLLs do the opposite: they use their linguistic repertoire to have access to the grammar. Therefore, the author holds that HLLs should study grammar as an analytical subject. Schwarzer and Petrón (2005) put forth a similar argument based on interviews with HLLs of Spanish, who declared that foreign language classes were of little use to them, given their limited (or non-existent) experience with the metalinguistic terminology used in those classes. For example, while FLLs of Portuguese may be able to describe the differences between the verbs ser and estar, they tend not to be able to apply that knowledge to their linguistic production (especially if they are monolingual speakers of a language that does not exhibit the same type of distinction). HLLs, on the other hand, tend to simply use those two verbs in appropriate contexts, even though they are often not able to explain why one verb is used and not the other. Therefore, classes that focus on naming and describing structures as opposed to analyzing their use may be of little use to the linguistic development of HLLs. What's worse, these classes may lead to lack of interest and motivation on the part of HLLs (BLANCO, 1987), who do not feel that they can gain much from instruction.

In order to maintain interest in language learning among HLLs and to help them develop their linguistic repertoire, authors such as Beaudrie, Ducar, and Potowski (2014), Burgo (2017) and Villa (1997), among others, have claimed that a sociolinguistic approach to language teaching, including in what related to grammar instruction, is best suited for HLLs. Concepts such as linguistic variation and code-switching, according to Villa (1997), are particularly useful in the heritage language class: HLLs learn that the language that their linguistic repertoire in the HL contains elements of languages in contact. According to Carvalho (2012, p. 149), code-switching should be incorporated in the HL classroom in order to create an environment where learners feel at ease as well as to better explore each learner's linguistic abilities.

While classes that are designed for FLLs may not suit the needs of HLLs, this is not to say that the latter group does not value the study of grammar. Villa (1997) highlights the affective dimension of studying grammar. According to the author, his students often stated that grammar study would help them "sound more educated and write better". Learners also perceived grammar as an intrinsic part of a university education. Thus, the author argues, learning grammar satisfies an affective dimension, especially when learners realize that the variety that they utilize "is chockfull of adverbs, adjectives, pronouns, complex verb tenses, and the like, emphasizing the validity of the grammatical structure of their spoken variety" (VILLA, 1997, p. 100). Empirical studies have validated Villa's claims. Lee (2002) reports that Korean HLLs expected more formal and academic language education than they had received. O'Rourke and Zhiou (2016) include samples of survey answers that show HLLs' frustration about not learning grammar in a STARTALK summer program. So, although grammar instruction should be tailored to the needs of specific groups of learners, studies have shown that HLLs appear to want to learn grammar (presumably) as much as do FLLs.

When tailoring instruction to the needs of groups of learners, it is important to give voice to them and take into consideration their opinions and preferences in what regards their learning. With that knowledge, it is possible to guide students so that they can take advantage of instruction and, where necessary, deconstruct certain beliefs about language learning. This study aims to contribute to the discussion on HLLs and FLLs perceptions on learning grammar by discussing 
results of a survey completed by university-level students enrolled in FL and HL Portuguese language courses.

After this introduction, the next section reviews some of the literature available on perceptions of heritage language learners, followed by a discussion of perceptions of foreign language learners in regards to grammar instruction and the research questions that guided this study. Then, the study methodology is presented, followed by analysis of the data and a discussion of the results, including possible pedagogical implications. Some concluding remarks, which include the limitations of the study, are offered in the last section.

\section{Perceptions of heritage language learners}

Research on views of heritage language learners has included issues related to motivation and attitude (e.g., ALARCÓN, 2010; BECKSTEAD; TORIBIO, 2003; CARREIRA; KAGAN, 2011; MIKULSKI, 2006; YANGUAS, 2010), classroom experience (e.g., EDSTROM, 2007; HARKLAU, 2009; SCHWARZER; PETRÓN, 2005), identity (e.g., ORIYAMA, 2010; TORRES, K., 2011; VENTURIN, 2019; WONG, XIAO, 2010), self-assessment of linguistic skills (e.g., SHINBO, 2004; SILVA, 2011; SWENDER ET AL., 2014), and language anxiety (e.g., GONTIJO; SILVA, 2013; LUO, 2015; TALLON, 2009; TORRES, K., 2011), among others. Some relevant results are outlined in what follows.

Research into HLLs' perceptions of their own linguistic skills has shown that these learners are, in general, confident in their abilities in what concerns speaking and listening, but not so much in relation to reading and writing (SHINBO, 2004; SILVA, 2011). Furthermore, several HLLs in Shinbo's (2004) study indicated that improving their grammar was one of the reasons for them to enroll in Japanese classes. However, several learners also voiced frustration with grammar study, since they were not familiar with the metalinguistic terminology used in the classroom (SHINBO, 2004, p. 74-75).

The lack of familiarity with metalanguage was also a source of frustration for the HLLs interviewed by Schwarzer and Petrón (2005), as previously mentioned. The authors interviewed three students enrolled in a Spanish as a heritage language class at a North American university. One of the participants, for example, wanted to work with bilingual education, but, although he was interested in Spanish language, he did not plan on taking any more classes because teachers "always talk about grammar and all that doesn't interest me at all" (SCHWARZER; PETRÓN, 2005, p. 572). According to the authors, the class that the participants attended could be characterized as a grammar class in which structures were presented in isolation, that is, without any contextualization. In the opinion of the HLLs interviewed for that study, explicit grammar lessons were not useful. Given their results, Schwarzer and Petrón (2005, p. 575) suggest that authentic materials be used in HL classes, and that lessons should go from understanding the whole first (such as reading a website in the target language) to analyzing parts later (such as grammatical structures used).

The two participants in Harklau's (2009) study, who were HLLs of Spanish in high school, had a different opinion about grammar lessons, at least when classes first started. According to the author, both students had a positive impression of grammar in their classes (HARKLAU, 2009, p. 224). However, by the end of a 2-year span, both learners expressed antipathy towards their Spanish language classes. The author clarifies that the change in opinion was due to several different factors, including the lack of instructor preparation to teach HL classes, which led to rejection of participants' varieties of Spanish and objectification of their cultures.

Mikulski (2006) reports that the goals of the four HLLs in her study (who were enrolled in a university-level Spanish for native speakers class) included mastery of grammar structures. As a matter of fact, "improve grammar/spelling" was the only item that all four participants considered a "very important" goal in the two questionnaires used in the study (MIKULSKI, 2006, p. 667). It 
was also the item with the highest score in self-reported progress, with a combined score of 31 (scale 0-10, average 7.75/participant; the lowest score was 4 , the highest was 10 ).

The differences in opinions about grammar instruction expressed by HLLs in the studies outlined above may be due to many different factors. However, it is clear that one of the most salient differences relates to the classroom experience they had and how well instructors were prepared to deal with the particularities of this group of students. While the participants in Schwarzer and Petrón's (2005) study were enrolled in a heritage language class, it was described as a grammar class where items were taught in isolation, not a class that catered to their specific needs. That scenario appears to have been quite different for the learners in Mikulski's study. The author mentions that the course instructor "was concerned because the Spanish of many of her students had been stigmatized in the past and she did not want them to feel that way again" and that she was relieved when she learned that the researcher did not intend to find out what was "wrong" with her students' Spanish (MIKULSKI, 2006, p. 664). This type of preoccupation demonstrates that the instructor was aware of sociolinguistic issues surrounding the language of HLLs, and that, most likely, was prepared to help them develop their linguistic skills, rather than inundate them with rules. This awareness does not appear to have been present among the high school teachers who taught the participants in Harklau's (2009) study, judging from the excerpts of interviews included in the article. Without this type of sociolinguistic knowledge on the part of the instructor, language classes are bound to frustrate or demotivate HLLs-or, worse, to alienate them by stigmatizing their contributions (ROCA, 1997).

Although little research is available on the perceptions of heritage language learners on grammar instruction, it is already clear that those views depend on the experience they have had in the classroom, among other factors. We also know that (at least some) heritage learners may want to develop their grammar skills. To shed more light on the issue, we turn next to the perceptions of foreign language learners on grammar teaching and learning.

\section{Views of foreign language learners on grammar instruction}

Grammar is often considered an essential part of foreign language instruction, one that instructors often feel comfortable with, given that rules make it tidy and easily testable. As Swan (2002, p. 149) puts it, "[l]earning grammar is a lot simpler than learning a language". However, Swan (2002, pp. 151-152) also calls attention for good reasons to teach grammar, namely comprehensibility and acceptability, noting that instructors should teach the points of grammar that are needed in light of those factors.

In a text that considers whether teaching grammar explicitly is a worthwhile effort, Ellis (2006, p. 95) explains that explicit knowledge consists of facts about a language that speakers have learned and can verbalize. Implicit knowledge, on the other hand, is held unconsciously and is easily available in fluent communication. The author suggests that explicit knowledge can help the development of implicit knowledge and, assuming that at least some grammatical features should be taught explicitly, he concludes that both deductive and inductive approaches to teaching grammar may be of value.

The difference between deductive and inductive grammar teaching was tackled by Fortune (1992). The study investigated learners' preferences in regards to the two types of grammar instruction in English as a second language (ESL, being learned in an English-speaking country, namely the UK). The participants in Fortune's study declared a preference for deductive learning (69\%) before being exposed to the inductive type of process. Afterwards, that percentage declined to $53 \%$, while the number of students who declared a preference for the inductive approach went from $24 \%$ to $42 \%$. Fortune $(1992$, p. 168 ) also notes that, in the opinion of many participants, the inductive approach should be reinforced by presenting the grammar rule in a later stage, and then 
by further practice. Therefore, following Eisenstein (1987), Fortune suggests that both approaches to grammar instruction may be useful, depending on how students prefer to learn.

In a study conducted at a North American university, Schulz (1996) compared students' and teachers' beliefs about the role of explicit grammar instruction in foreign language classrooms. In her study, $80 \%$ of the students (as opposed to $64 \%$ of teachers) agreed that "the formal study of grammar is essential to eventual mastery of the language" (SCHULZ, 1996, p. 345). Almost half of the students (48\%) also stated that studying and practicing grammar is best for improving communicative abilities. Although most learners in her study agreed that grammar is useful in foreign language learning, the majority did not indicate that they liked or wanted more grammar study. Still, Schulz notes (1996, p. 345), a "surprising" 46\% of student participants asserted that they did like to study grammar and $26 \%$ would like to have more grammar in their lessons. In what concerns pedagogical implications of her findings, the author suggests that learner opinions be taken into account when planning lessons, noting that "perceptions influence reality", even if they do not necessarily correspond to the cognitive processes that happen in language learning (SCHULZ, 1996, p. 349).

While Schulz's 1996 study revealed views of learners and instructors in a U.S. institution, a later study (SCHULZ, 2001) shows that beliefs regarding grammar instruction may be culturally bound to a certain extent. In a survey of learners of English as a foreign language (EFL) in Colombia, $76 \%$ of participants stated that they liked the study of grammar; $77 \%$ agreed that their English would improve most quickly if they studied and practiced grammar; and 51\% thought that there should be more formal study of grammar in their EFL courses (SCHULZ, 2001, p. 247). When compared with the results detailed in the 1996 study (46\%, 48\%, and 26\%), it's clear that students in Colombia place higher value in formal grammar instruction than do their counterparts in the U.S. However, it is important to note that most U.S. and Colombian students believed that practicing the foreign language in real-life situations helped their linguistic development more than studying grammar (SCHULZ, 2001, p. 251).

If the native culture of learners influences their views on grammar instruction, so does the language they learn. Loewen et al. (2009) surveyed 754 students of 14 different foreign languages (as well as learners of ESL) at a North American university and found that those enrolled in a group of less commonly taught languages (Korean, Turkish, Thai, Persian, Nepali, and Urdu) had the most positive attitudes toward the role of grammar in L2 learning. The least positive attitudes were expressed by the ESL learners. The authors also report that the leaners of Japanese were the least likely to prioritize communication over grammar, while learners of Italian and Portuguese (which were grouped together in the study) were among those more likely to do so. Besides a questionnaire, Loewen et al.'s study also included open-ended prompts, which revealed that many participants believed that grammar provided a foundation for their linguistic knowledge and that it helped them with specific aspects of the language (writing, reading, speaking, listening). Although some learners stated that they enjoyed studying grammar, others did not: over half of the participants had negative comments about grammar study, including complaints about rules and exceptions. The authors conclude that "it is clear that the learners valued grammar instruction", though "not everyone valued grammar instruction equally" (LOEWEN ET AL., 2009, p. 101).

The idea that FL learners consider grammar instruction important is corroborated in other studies, such as Ahmadi and Shafiee (2015), who investigated EFL teachers' and learners' views in language institutes in an Iranian locality; Saaristo (2015), who looked at views of university students in Finland (reporting on opinions both on the role of grammar in mother tongue and in FL development); and Sogutlu and Veliaj-Ostrosi (2016), who surveyed EFL learners in Albana.

Drawing on Spada and Lightbown (2008), who distinguish between isolated and integrated grammar instruction (ie, activities that are separate from or in the context of communicative activities), Spada and Lima (2015) report on the preferences of ESL and EFL teachers and learners. Spada and Lightbown (2008) note that integrated grammar instruction includes a variety of 
approaches that can contribute to the automatization of language features, but isolated lessons may be useful for learners as well (SPADA; LIGTBOWN, 2008, p. 200). Spada and Lima (2015) confirm that teachers and learners see value in both types of approaches. They present results from two studies: a questionnaire study and a feedback study. Their questionnaire study included 294 ESL learners in Canada and 175 EFL learners in Brazil; their feedback study, done after both integrated and isolated materials were used in lessons, included 102 ESL and 63 EFL students. Spada and Lima (2015) report a preference for integrated over isolated grammar instruction among EFL students (and teachers) in both studies. ESL learners as well as teachers stated a preference for integrated instruction in the questionnaire study, but revealed a slight preference for isolated instruction in the feedback study. The authors note, however, that the slight imbalance may be due to more opportunities for output practice in the isolated materials used in the ESL group (SPADA; LIMA, 2015, p. 187). The authors conclude that, although participants expressed some preference for integrated over isolated grammar instruction, the results do not mean that they do not value isolated activities, since results are influenced by several factors, such as proficiency level, language feature taught and individual learning preferences (SPADA; LIMA, 2015, p. 188).

The findings discussed in this and in the previous section show that perceptions of learners regarding grammar instruction has been at the center of several studies in FL/L2 education, but we still know little about heritage language learners. The present study intends to contribute to the discussion on learners' perceptions as well as to heritage language education by comparing the views of FLLs and HLLs enrolled in Portuguese language courses. The questions that guided this study were:

1. What kind of grammar instruction do Portuguese heritage language learners prefer? Formal or contextualized?

2. What kind of Portuguese foreign language learners prefer? Formal or contextualize?

3. Do Portuguese heritage and foreign language learners believe that explicit grammar instruction helps their linguistic development?

As explained in section 5 below, "formal instruction" refers to grammar practice that is decontextualized and detached from other activities. "Contextualized" grammar practice, on the other hand, relates to instruction that focuses on use of language and to grammar instruction that is integrated with other activities. The next section presents the methodology used in this project and includes information on the study participants.

\section{Methodology}

The present study was conducted at a public university in the New England region of the United States. This region is home to a significant number of Portuguese-speaking immigrants and their descendants (U.S. CENSUS BUREAU, 2016). The study, which was approved by the Institutional Review Board at the university (IRB \# 18.045 of April 5, 2018), included a background questionnaire and a survey with 24 statements. The instrument was distributed among students enrolled in four Portuguese language courses, including a course designed specifically for heritage learners, in the Spring of 2018. Although the university offers Portuguese as a heritage language courses, many HLLs enroll in courses designed to teach Portuguese as a foreign language. The background questionnaire and the survey were completed during class time; participants took about 15 minutes to complete them.

The background questionnaire consisted of four questions and was used to determine whether participants were heritage or foreign language learners. Participants who included "Portuguese" in question 1 ("What language(s) did your relatives speak when you were growing 
up?") and/or in question 2 ("What language(s) did you speak when you were growing up?") were considered to be heritage learners $(n=30)$. The others $(n=28)$ were considered foreign language learners. Out of the 28 FLLs who participated in the study, 22 were monolinguals (ie, had only been exposed to English in the home environment) and 6 had been exposed to other languages in their childhood (namely, Arabic, Cantonese, Greek, Khmer, Lithuanian, and Thai) and are likely bilingual (to some degree, at least) in English and those languages.

The third question in the background questionnaire related to the class in which participants were enrolled ("What Portuguese class are you currently taking?"). The university where the survey was administered offers a 2-semester Portuguese for heritage learners (PHL) track as well as two different Portuguese as a foreign language (PFL) tracks: a 4-semester sequence and an intensive 2-semester sequence. Every Spring term the university offers the second and the fourth courses in the 4-semester PFL track (namely, elementary II and intermediate II), the second course in the PFL intensive sequence (intensive intermediate) and the second course in the PHL track (PHL II). Participants were enrolled in all four courses, to wit: 26 in elementary II, 21 in intermediate II, 5 in intensive intermediate and 6 in PHL II.

The fourth and last background question asked: "Have you learned (or studied) any other language(s)? Which?". Six of the 28 FLLs who filled out the survey had studied Spanish (including 2 of the 6 bilinguals, ie, FLLs who had been exposed to other languages in childhood), the EnglishGreek bilingual had studied Spanish and German, and the English-Cantonese bilingual had studied Mandarin. Out of the 30 HLLs, 10 had studied Spanish, 2 had studied French, 2 had studied both Spanish and French, and one had studied German. The remaining 22 participants had only studied Portuguese.

Participants were all college age (typically, 18-24), although no specific information about age was collected. Even though participants provided information about the Portuguese language classes in which they were enrolled, they were not asked to participate in tests that might determine their actual proficiency in Portuguese. Such tests would have required time for which participants would have to be compensated, not to mention the likely need for research assistants. Given the lack of a budget for such expenses, it was not possible to carry out proficiency tests.

For the survey, participants were asked to rate statements about grammar learning in a Likert-type scale that included five possibilities: 1 (strongly disagree), 2 (disagree), 3 (neither agree nor disagree), 4 (agree), and 5 (strongly agree). Of the original 24 statements, 23 were analyzed for this study. One statement was excluded because its wording was too similar to that of another statement (as expected, the two statements were rated similarly). The survey was developed by the author and was based on the instruments used in Loewen et al. (2009), Schulz (1996, 2001), and Spada and Lima (2015).

\section{Data analysis}

The statements in the survey were rated in a Likert-type scale (from 1=strongly disagree to $5=$ strongly agree). Of the 23 statements analyzed, 10 related to formal or isolated instruction, focusing on grammar itself. Ten other statements pointed to contextualized or integrated grammar practice, focusing on meaning and language use. For ease of reference, the first group of statements is called "formal instruction/practice", while the latter is referred to as "contextualized instruction/practice". Table 1 shows the results for each statement that relates to formal or explicit grammar instruction; Table 2 displays the values concerning contextualized or non-explicit grammar practice. 
Table 1. Results for formal grammar study

\begin{tabular}{|c|c|c|}
\hline Statement & HLLs & FLLs \\
\hline I like to know the names of verb tenses and other grammatical structures in Portuguese. & 3.6 & 3.78 \\
\hline Before reading a text, I like to study the grammar used in it. & 3.13 & 3.1 \\
\hline In order to learn Portuguese, it's very important to do grammar exercises. & 3.56 & 3.78 \\
\hline I learn Portuguese grammar by memorizing the rules. & 3.43 & 3.53 \\
\hline Studying grammar formally is essential for learning Portuguese. & 3.46 & 3.67 \\
\hline My skills in Portuguese improve most quickly if I study the grammar. & 3.43 & 3.71 \\
\hline Knowledge about grammar rules helps me understand spoken Portuguese. & 3.73 & 3.53 \\
\hline I find it helpful to study grammar separately from communicative activities. & 3.36 & 3.71 \\
\hline I would like to have more formal study of grammar in Portuguese class. & 2.76 & 3.28 \\
\hline Portuguese class should focus on grammar rules. & 3.3 & 3.53 \\
\hline Mean & 3.37 & 3.5 \\
\hline
\end{tabular}

Table 2. Results for contextualized grammar practice

\begin{tabular}{|c|c|c|}
\hline Statement & HLLs & FLLs \\
\hline I like learning grammar during writing, speaking, reading or listening activities. & 3.86 & 3.17 \\
\hline I prefer to practice Portuguese grammar in context than going over grammar rules. & 3.86 & 3.5 \\
\hline I can use the language even if I can't name grammatical structures in Portuguese. & 3.9 & 3.14 \\
\hline It is more important to practice Portuguese in real-life situations than to learn about grammar rules. & 3.83 & 3.82 \\
\hline Grammar should be taught during communicative activities. & 3.56 & 3.32 \\
\hline I learn Portuguese grammar by using the language. & 4.06 & 3.72 \\
\hline I can communicate in Portuguese without knowing the rules explicitly. & 3.4 & 2.85 \\
\hline I would like to have more contextualized language practice in Portuguese class. & 3.83 & 3.67 \\
\hline Portuguese class should focus on communication in the language. & 4.2 & 3.85 \\
\hline Grammar can be learned as we work on different skills and activities. & 4.2 & 4 \\
\hline Mean & 3.87 & 3.56 \\
\hline
\end{tabular}

Tables 1 and 2 show FLLs expressed a somewhat higher preference for formal grammar study than did HLLs, while the HLLs who participated in this study are more likely than the FLLs to prefer grammar instruction that is integrated within contextualized activities. The data in these tables also reveal that the opinions of these two cohorts of learners are nuanced, not absolute. As an example, HLLs rated the statement "Portuguese class should focus on communication in the language" highly: 4.2/5. Nevertheless, they also attributed some value $(3.73 / 5)$ to the statement "Knowledge about grammar rules helps me understand spoken Portuguese". The same type of apparent contradiction was revealed by FLLs, who seem to find it somewhat helpful to study grammar separately from communicative activities $(3.71 / 5)$, but, at the same time, also think that grammar can be learned as they work on different skills and activities (4/5). These numbers bring to light the fact that groups of learners are not monolithic: there is variation within these groups, especially in what concerns individual learning preferences. Furthermore, the fact that they state preferences that may seem divergent shows that they may in fact see value in both types of instruction, even if one seems to be more appealing than the other.

The values assigned by HLLs and FLLs to each type of grammar practice (formal/explicit and contextualized/non-explicit) were compared in order to assess differences among expressed preferences. In order to determine statistical significance, a Student's t-test was performed. Table 3 displays the mean values for each group and for each type of grammar instruction, as well as the pvalue and the standard error (SE) revealed by the $t$-test.

Table 3. Formal and contextualized grammar practice: Student's t-test (intragroup)

\begin{tabular}{lllll}
\hline & Formal & Contextualized & $p$ value & SE \\
\hline HLLs $(\mathbf{n}=\mathbf{3 0})$ & 3.376 & 3.87 & $<0.001$ & 0.118 \\
\hline FLLs $(\mathbf{n}=\mathbf{2 8})$ & 3.562 & 3.504 & 0.68 & 0.137 \\
\hline
\end{tabular}


As Table 3 shows, this cohort of Portuguese HLLs expressed a clear preference for contextualized over formal grammar practice: a p-value of less than 0.05 is considered statistically significant (MCLEOD, 2019). Learners who were studying Portuguese as a foreign language, on the other hand, appeared not to have a definitive preference. Although the mean value for formal grammar instruction is slightly higher than the one for contextualized practice, a $p$-value of 0.68 shows that FLLs expressed no obvious preference for one or the other type of grammar practice.

Another way to look at the data is to compare the averages between HLLs and FLLs. As shown in Table 4, when the two groups of learners are compared to each other, there is a significant difference in relation to preferences regarding contextualized practice. However, while FLLs showed a somewhat higher preference for formal grammar practice than did HLLs, that difference in not statistically significant.

Table 4. Formal and contextualized grammar practice: Student's t-test (intergroup)

\begin{tabular}{lllll}
\hline & HLLs $(\mathbf{n}=30)$ & FLLs $(\mathbf{n}=28)$ & $p$ value & SE \\
\hline Contextualized & 3.87 & 3.504 & 0.0205 & 0.142 \\
\hline Formal & 3.376 & 3.562 & 0.11 & 0.111 \\
\hline
\end{tabular}

The preference stated by HLLs regarding contextualized practice is corroborated by the intergroup comparison displayed in Table 4. When compared to FLLs, HLLs demonstrated a stronger-and statistically significant-preference for contextualized practice.

The survey also contained statements related to explicit grammar instruction. It is important to note that explicit instruction is not necessarily opposed to contextualized instruction. Researchers such as Long (1991) and Ellis $(2003,2016)$ have argued that it is possible to target linguistic forms that arise in context, a procedure called "focus on form" by Long (1991). Ellis (2016, p. 411) maintains that, in a communicative context, learners' attention may be drawn implicitly or explicitly to linguistic forms. In other words, it is possible to have explicit instruction on linguistic forms that is integrated with other activities and not decontextualized. Therefore, it makes sense to inquire about learners' opinions on explicit grammar teaching and learning. Two statements included in the survey addressed that topic. Table 5 contains the average of the results related to those two statements as well as results of Student's t-test ( $p$-value and standard error). Table 6 shows the percentages of HLLs and FLLs selecting each alternative.

Table 5. Explicit grammar instruction: Averages and t-test results

\begin{tabular}{lllll}
\hline Statement & HLLs & FLLs & $p$-value & SE \\
\hline I learn grammar rules when they are explained explicitly. & 4.16 & 4 & 0.47 & 0.228 \\
\hline $\begin{array}{l}\text { Explicit grammar instruction contributes in a } 3.56 \\
\text { fundamental way to my linguistic development in }\end{array}$ & & 3.78 & 0.44 & 0.283 \\
Portuguese. & & & \\
\hline
\end{tabular}

Table 6. Explicit grammar instruction: Percentages of participants selecting each alternative

\begin{tabular}{lllllc} 
& Strongly disagree & Disagree & $\begin{array}{l}\text { Neither agree nor } \\
\text { disagree }\end{array}$ & Agree & Strongly agree \\
\hline HLLs & I learn grammar rules when they are explained explicitly. & & 36.7 \\
FLLs & 3.3 & 0 & 10 & 50 & 28.5 \\
\hline & 0 & 7.2 & 14.3 & 50 & 23.3 \\
HLLs & 10 & 3.3 & 30 & 33.4 & 17.8 \\
FLLs & 3.6 & 7.2 & 14.3 & 57.1 & \\
\hline
\end{tabular}

Participants in this study assign value to explicit instruction of grammar features: on average, both groups of learners agreed with statement "I learn grammar rules when they are explained explicitly". Table 6 shows that $86.7 \%$ of HLLs and $78.5 \%$ of FLLs either agreed or strongly agreed 
with the statement. Agreement is less strong in what relates to the effect that explicit grammar teaching may have on their linguistic development. Still, on average, both heritage and foreign language learners leaned towards agreement with the second statement, even if HLLs did not agree as strongly as FLLs did: $56.4 \%$ of HLLs and $74.9 \%$ of FLLs either agreed or strongly agreed with the second statement, as shown in Table 6. The intergroup comparison does not reveal a statistically significant difference between the groups for either statement, as shown by the results displayed in Table 5, which suggests that both groups find explicit grammar instruction a worthwhile effort.

Finally, one statement in the survey addressed learners' perception of the difficulty posed by Portuguese grammar: "Portuguese grammar rules are very difficult to learn". Perhaps unsurprisingly, FLLs rated this statement more highly than did HLLs: 4/5 among the former, 3.63/5 among the latter. Still, HLLs do not necessarily find grammar an easy topic: no statistically significant difference between the groups was observed, with a $p$-value of 0.15 , standard deviation of 0.367 and standard error of 0.252 . Heritage learners in other studies (MIKULSKI, 2006; SHINBO 2004) mentioned that they wanted to improve their grammar. Given that HLLs learn the language in a naturalistic environment, many may not have had access to grammar studies in Portuguese before starting classes at university, and thus do not find grammar a topic that is easy to tackle, especially if instruction involves metalinguistic knowledge such as names of verb tenses or of parts of speech. The next section contains a discussion of these results in relation to the research questions that guided the study, as well as pedagogical implications.

\section{Discussion}

The first research question that guided this study asked if heritage learners of Portuguese preferred grammar instruction that was focused on grammar itself or if they favored grammar practice that was integrated with other activities and/or focused on language use. The HLLs who answered the survey expressed a preference for grammar instruction that is contextualized and/or integrated with other activities. This is not to say, however, that this group of learners does not see any value in formal grammar instruction. The HLLs in the present study appear to see benefits in formal practice, as indicated by a mean of 3.376 out of 5 . Only the statement "I would like to have more formal study of grammar in Portuguese class" was ranked below 3.0 by HLLs, and one of the statements regarding formal grammar study was actually ranked higher by HLLs than by FLLs: "Knowledge about grammar rules helps me understand spoken Portuguese" (3.73/5). This particular rating is somewhat unexpected, given that HLLs are exposed to their heritage language mainly in spoken form and tend to rank their own listening skills quite highly (CARREIRA; KAGAN, 2011; SHINBO, 2004; SILVA, 2011). Thus, it appears that, at least for this group of heritage learners, class should focus on communicating in Portuguese, but instruction on grammar rules may help them in their listening abilities, even if they have been exposed to Portuguese since early childhood. So, although the HLLs who participated in this study favor grammar instruction that is contextualized, they also see some value in instruction that is directed exclusively at grammar features.

After addressing the preferences expressed by participants who were learning Portuguese as a heritage language, the second research question in this study was concerned with learners for whom Portuguese was a foreign language (ie, those who were not exposed to it in the familial context): what type of grammar instruction do they favor? As seen in the previous section, the FLLs who participated in this study did not express a clear preference for either type of approach to grammar teaching and learning. As a group, they seemed to perceive both types of instruction as useful. This finding endorses Spada and Lightbown's (2008, p. 200) claim that integrated and isolated form-focused instruction may have a different role in language learning. However, it is 
worth noting that, like the participants in Schulz's studies $(1996,2001)$, both groups of students consider practicing Portuguese in real-life situations more important than studying grammar.

The third research question guiding this study related to explicit instruction: Do Portuguese heritage and foreign language learners believe that explicit grammar instruction help their linguistic development? The survey filled out by participants included two statements directed at explicit grammar instruction. Both groups of learners rated those statements similarly. The largest difference between the groups was of only 0.28 points and was found in the statement that received the lowest rating by HLLs (3.56): "Explicit grammar instruction contributes in a fundamental way to my linguistic development in Portuguese". It is not surprising that HLLs would attribute a lower rating to this statement than FLLs. What seems surprising is that several HLLs rated it so highly: $56.6 \%$ of HLLs (17/30) agreed or strongly agreed with that statement. Equally unexpected (if not more so) was the rating attributed by HLLs to the other statement, "I learn grammar rules when they are explained explicitly". Heritage learners rated this item 4.16, while FLLs rated it 4 . This result corroborates findings such as those reported by Montrul and Bowles (2010), who attested significant gains by Spanish HLLs after they received explicit instruction concerning two grammatical features (specifically, differential object marking-the personal $a$-and dative experiencers with gustar-type verbs).

In terms of pedagogical implications, the findings in this study show that not only do HLLs and FLLs have different instructional needs, but they also display (somewhat) different preferences, at least in what relates to grammar instruction. The preference expressed by HLLs for contextualized grammar instruction supports suggestions put forth by authors such as Carreira (2016) and Parra, Bravo and Polinsky (2018), who defend that grammar instruction for heritage learners should be "dictated by function and context" (CARREIRA, 2016, p. 125). However, both groups see value in formal grammar instruction as well. Therefore, while many if not most activities designed for heritage language classes or for mixed classes (which have both FLLs and HLLs) should in fact be integrated with other activities, there may be room for isolating a certain grammatical structure that may present special challenges. As noted by Ellis (2016, p. 410) the two approaches should be thought of as part of a continuum. Perhaps, then, there may be room for both types of approach, even if one is favored.

Participants in this study also consider that explicit grammar teaching is important. Foreign language classes have traditionally incorporated explicit instruction (the first $\mathrm{P}$ in the famous PPP procedure-presentation-practice-production). In what concerns heritage language instruction, however, the picture may be different. Given that HLLs have been exposed to the language in naturalistic settings, they tend not to be as familiar with metalinguistic terminology as FLLs are and tend not to do as well in tasks that involve this type of knowledge (BEAUDRIE, 2009; POTOWSKI; JEGERSKI; MORGAN-SHORT, 2009; TORRES, J., 2018). Nevertheless, other authors have called for the inclusion of explicit instruction in the heritage language classroom, either for a particular feature (BEAUDRIE, 2017) or more broadly (PARRA; BRAVO; POLINSKY, 2018). For cases of mixed classes (those with both FLLs and HLLs), the findings in Bowles (2011), Edstrom (2007) and in Randolph (2017), as well as the suggestions provided by Burgo (2017) and by Carreira (2017) can be very helpful. Those findings and suggestions are outside of the scope of this paper, however. For our purposes, suffice it to say that interactions between the two types of learners can be quite productive: for example, the heritage learners in Edstrom's (2007) study stated an appreciation of FLLs' ability to explain grammar rules, while Bowles (2011) reports that FLLs may rely on HLLs' lexical knowledge (Bowles, 2011). The final section offers some concluding remarks, including limitations of the present study. 


\section{Conclusion}

The field of $\mathrm{L} 2 /$ foreign language education has debated issues related to grammar instruction for decades, and is likely to continue to do so (Ellis, 2006). In heritage language education, which is a more recent field of study, there is consensus that HLLs differ from FLLs, and, therefore, teaching approaches (including grammar teaching) should be different for the two groups of learners. This paper has contributed to this debate by presenting data related to the preferences expressed by students learning Portuguese as a heritage and as a foreign language. While HLLs stated a clear preference for contextualized approaches to instruction over formal grammar study, the FLLs who participated in the study did not express a clear preference. The preference expressed by HLLs does not mean that they see no value in studying grammar formally, separately from other activities. Furthermore, both groups attached value to explicit grammar instruction-noting, again, that explicit does not oppose contextualized: focus-on-form activities, as Ellis (2016) explains, can call attention to grammatical features (such as explicit correction) while learners are engaged in activities that focus on meaning. Knowing about learners' expressed preferences may help instructors plan their lessons so as to provide opportunities that benefit different learners.

The present study has shed light on the views of heritage and foreign language learners of Portuguese regarding grammar instruction, and, as such, has contributed to the debate on grammar teaching as well as to the fields of heritage language education and Portuguese language teaching. However, some limitations of the study must be noted. Questionnaires such as the one used in this study are, by nature, limiting, since they require that participants respond to the stated question. Furthermore, data collection was carried out during class periods, which meant that the questionnaire had to be short enough to be answered in no more than 15 minutes.

Another limitation relates to the type of data obtained. The instrument used was quantitative only and there was no space (or time) for open-ended answers. Qualitative data may have helped in drawing a clearer picture of learners' perceptions. Finally, we do not know what Portuguese language teachers believe about grammar instruction. Comparing instructors' and students' views may be useful to detect similarities and dissimilarities, so that instructors can better tailor their practice to the needs of their students.

The limitations outlined here provide a blueprint for future research. Qualitative data should be used to allow learners to elaborate on their views. Besides open-ended questions, interviews with at least a few learners from each group would allow for in-depth probing of their perspectives. It would also be important to compare and contrast the perceptions of Portuguese language instructors to those of learners. It is hoped that more research on the views of Portuguese heritage and foreign language learners as well as instructors will add to the findings of the present study.

\section{References}

AHMADI, F.; SHAFIEE, S. L2 teachers' and learners' beliefs about grammar. International Journal of Language Learning and Applied Linguistics World, v. 9, n. 1, pp. 245-261, 2015.

ALARCÓN, I. Advanced heritage learners of Spanish: A sociolinguistic profile for pedagogical purposes. Foreign Language Annals, v. 43, n. 2, pp. 269-288, 2010.

BEAUDRIE, S. M. Receptive bilinguals' language development in the classroom: The differential effects of heritage versus foreign language curriculum. In: LACORTE, M.; LEEMAN, J. (Eds.). Español en Estados Unidos y otros contextos de contacto: Sociolingüística, ideología y pedagogía. Madrid: Iberoamericana/Vervuert Verlag, 2009. pp. 325-346. 
BEAUDRIE, S. M. The teaching and learning of spelling in the Spanish heritage language classroom: Mastering written accent marks. Hispania, v. 100, n. 4, pp. 596-611, 2017.

BEAUDRIE, S. M.; DUCAR, C.; POTOWSKI, K. Heritage language teaching: Research and practice. Columbus, Ohio: McGraw-Hill Education, 2014.

BECKSTEAD, K.; TORIBIO, A. J. Minority perspectives on language: Mexican and MexicanAmerican adolescents' attitudes toward Spanish and English. In: ROCA, A; COLOMBI, M. C. (Eds.). Mi lengua: Spanish as a heritage language in the United States. Washington, DC: Georgetown University Press, 2003. pp. 154-169.

BLANCO, G. Español para el hispanohablante: Función y noción. Austin, TX: Texas Education Agency, 1987.

BOWLES, M. Exploring the role of modality: L2-heritage learner interactions in the Spanish language classroom. Heritage Language Journal, v. 8, n. 1, pp. 30-65, 2011. Retrieved from: https://www.heritagelanguages.org/. Date of access: 3 Dec. 2011.

BURGO, C. Meeting student needs: Integrating Spanish heritage language learners into the second language classroom. Hispania, v. 100, n. 5, pp. 45-50, 2017.

CARREIRA, M. Supporting heritage language learners through macrobased teaching: Foundational principles and implementation strategies for heritage language and mixed classes. In: FAIRCLOUGH, M.; BEAUDRIE, S. (Eds.). Innovative strategies for heritage language teaching: A practical guide for the classroom. Washington, DC: Georgetown University Press, 2016. pp. 123-142. CARREIRA, M. Learning for all: Addressing issues of access and participation in mixed classes. Hispania, v. 100, n. 5, pp. 51-52, 2017.

CARREIRA, M.; KAGAN, O. The results of the National Heritage Language Survey: Implications for teaching, curriculum design, and professional development. Foreign Language Annals, v. 44, n. 1, pp. 40-64, 2011.

CARVALHO, A. M. Code-switching: From theoretical to pedagogical considerations. In: BEAUDRIE, S.; FAIRCLOUGH, M. (Eds.). Spanish as a heritage language in the United States: State of the field. Washington, DC: Georgetown University Press, 2012. pp. 139-160.

CUMMINS, J. Linguistic interdependence and the educational development of bilingual children. Review of Educational Research, v. 49, pp. 222-251, 1979.

EDSTROM, A. The mixing of non-native, heritage and native speakers in upper-level Spanish courses: A sampling of student opinion. Hispania, v. 90, n. 4, pp. 755-768, 2007.

EISENSTEIN, M. Grammatical explanations in ESL: Teach the student, not the method. In: LONG, M.; RICHARDS, J. (Eds.). Methodology in TESOL. New York: Harper \& Row, 1987. pp. 282-297.

ELLIS, R. Task-based language learning and teaching. Oxford: Oxford University Press, 2003.

ELLIS, R. Current issues in the teaching of grammar: An SLA perspective. TESOL Quarterly, v. 40, n. 1, pp. 83-107, 2006. Retrieved from https://www.jstor.org/stable/40264512. Date of access: 26 Sept. 2019.

ELLIS, R. Focus on form: A critical review. Language Teaching Research, v. 20, n. 3, pp. 405-428, 2016.

FORTUNE, A. Self-study grammar practice: learners' views and preferences. ELT Journal, v. 46, n. 2, pp. 160-171, 1992.

FRIEDMAN, D.; KAGAN, O. Academic writing proficiency of Russian heritage speakers. In: BRINTON, D.; KAGAN, O.; BAUCKUS, S. (Eds.). Heritage language education: A new field emerging. New York \& Abingdon: Routledge, 2008. pp. 181-198.

GONTIJO, V.; SILVA, G.V. A ansiedade no aprendizado de português como língua estrangeira e português como língua de herança. In: SILVA, K.A.; SANTOS, D.T. (Eds.). Português como língua (inter)nacional: Faces e interfaces. Campinas, SP: Pontes, 2013. pp. 47-67. 
192 | Gláucia Silva

HARKLAU, L. Heritage speakers' experience in new Latino diaspora Spanish classrooms. Critical Inquiry in Language Studies, v. 6, n. 4, pp. 211-242, 2009.

LEE, J. S. The Korean language in America: The role of cultural identity in heritage language learning. Language, Culture and Curriculum, v. 15, n. 2, pp. 117-133, 2002.

LOEWEN, S., et al. Second language learners' beliefs about grammar instruction and error correction. The Modern Language Journal, v. 93, n. 1, pp. 91-104, 2009.

LONG, M. Focus on form: A design feature in language teaching methodology. In: DE BOT, K.; GINSBERG, R.; KRAMSCH, C. (Eds.). Foreign language research in cross-cultural perspective. Amsterdam: John Benjamins, 1991. pp. 39-52.

LUO, H. Chinese language learning anxiety: A study of heritage learners. Heritage Language Journal, v. 12, n. 1, pp. 22-47, 2015. Retrieved from: https://www.heritagelanguages.org/. Date of access: 10 May 2016.

LYNCH, A. Toward a theory of heritage language acquisition. In: ROCA, A; COLOMBI, M. C. (Eds.). Mi lengua: Spanish as a heritage language in the United States. Washington, DC: Georgetown University Press, 2003. pp. 25-50.

McLEOD, S. A. What a p-value tells you about statistical significance, 2019. Retrieved from https://www.simplypsychology.org/p-value.html. Date of access: 26 Sept. 2019.

MIKULSKI, A. M. Accent-uating rules and relationships: Motivations, attitudes, and goals in a Spanish for Native Speakers class. Foreign Language Annals, v. 39, n. 4, pp. 660-682, 2006.

MONTRUL, S. The acquisition of heritage languages. Cambridge: Cambridge University Press, 2016.

MONTRUL, S.; BOWLES, M. Is grammar instruction beneficial for heritage language learners?

Dative case marking in Spanish. Heritage Language Journal, v. 7, n. 1, pp. 47-72, 2010. Retrieved from https://www.heritagelanguages.org/. Date of access: 5 Oct. 2012.

ORIYAMA, K. Heritage language maintenance and Japanese identity formation: What role can schooling and ethnic community contact play? Heritage Language Journal, v. 7, n. 2, pp. 76-111, 2010. Retrieved from: https://www.heritagelanguages.org/. Date of access: 14 Apr. 2014.

O'ROURKE, P.; ZHOU, Q. Heritage and second language learners: Different perspectives on language learning. International Journal of Bilingual Education and Bilingualism, v. 21, n. 8, pp. 9941003, 2018.

PARODI, C. Stigmatized Spanish inside the classroom and out: A model of language teaching to heritage speakers. In: BRINTON, D.; KAGAN, O.; BAUCKUS, S. (Eds.). Heritage language education: A new field emerging. New York \& Abingdon: Routledge, 2008. pp. 199-214.

PARRA, M. L.; BRAVO, M. L.; POLINSKY, M. De bueno a muy bueno: How pedagogical intervention boosts language proficiency in advanced heritage learners. Heritage Language Journal, v. 15, n. 2, pp. 203-241, 2018. Retrieved from: https://www.heritagelanguages.org/. Date of access: 25 Feb. 2019.

PEIRCE, G. Representational and processing constraints on the acquisition of case and gender by heritage and L2 learners of Russian: A corpus study. Heritage Language Journal, v. 17, n. 1, pp. 95 115, 2018. Retrieved from: https://www.heritagelanguages.org/. Date of access: 25 Feb. 2019.

RANDOLPH, L. Heritage language learners in mixed Spanish classes: Subtractive practices and perceptions of high school Spanish teachers. Hispania, v. 100, n. 2, pp. 274-288, 2017.

ROCA, A. La realidad en el aula: logros y expectativas en la enseñanza del español para estudiantes bilingües. In: COLOMBI, M.C.; ALARCÓN, F. (Eds.). La enseñanza del español a hispanohablantes: Praxis y teoria. Boston: Houghton Mifflin, 1997. pp. 55-64.

SAARISTO, P. Grammar is the heart of language: grammar and its role in language learning among Finnish university students. In: JALKANEN, J.; JOKINEN, E.; TAALAS, P. (Eds.). Voices of pedagogical development - Expanding, enhancing and exploring higher education language learning. Dublin: Research-publishing.net, 2015. pp. 279-318. Retrieved from: https://doi.org/10.14705/rpnet.2015.9781908416261. Date of access: 16 Mar. 2018. 
SCHULZ, R. Focus on form in the foreign language classroom: Students' and teachers' views on error correction and the role of grammar. Foreign Language Annals, v. 29, n. 3, pp. 343-364, 1996.

SCHULZ, R. Cultural differences in student and teacher perceptions concerning the role of grammar instruction and corrective feedback: USA: Colombia. The Modern Language Journal, v. 85, n. 2, pp. 244-258, 2001.

SCHWARZER, D.; PETRÓN, M. Heritage language instruction at the college level: Reality and possibilities. Foreign Language Annals, v. 38, n. 4, pp. 568-578, 2005.

SHINBO, Y. Challenges, needs and contributions of heritage language students in foreign language classrooms. 2004. 147 p. Thesis (MA in Foreign Language Education and Applied Linguistics) - Department of Language and Literacy Education, University of British Columbia. Retrieved from https://open.library.ubc.ca/cIRcle/collections/ubctheses/831/items/1.0078382. Date of access: 24 Sept. 2019.

SILVA, G.V. Textbook activities among heritage and non-heritage Portuguese learners. Hispania, v. 94, n. 4, pp. 734-750, 2011.

SOGUTLU, E.; VELIAJ-OSTROSI, M. Learners' beliefs of the role of grammar in EFL learning. European Academic Research, v. 4, n. 1, pp. 310-328, 2016.

SPADA, N.; LIGHTBOWN, P. M. Form-focused instruction: Isolated or integrated? TESOL Quarterly, v. 42, n. 2, pp. 181-207, 2008.

SPADA, N; LIMA, M. S. Teacher and learner preferences for integrated and isolated form-focused instruction. In: CHRISTISON, M.; CHRISTIAN, D.; DUFF, P.; SPADA, N. (Eds.). Teaching and learning English grammar. New York; Abingdon: Routledge, 2015. pp. 178-193.

SWAN, M. Seven bad reasons for teaching grammar - and two good ones. In: RICHARDS, J. C.; RENANDYA, W. A. (Eds.). Methodology in language teaching: An anthology of current practice. Cambridge; Cambridge University Press, 2002. pp. 148-152.

SWENDER, E.; MARTIN, C.; RIVERA-MARTÍNEZ, M.; KAGAN, O. Exploring oral proficiency of heritage speakers of Russian and Spanish. Foreign Language Annals, v. 47, n. 3, pp. 423-446, 2014. TALLON, M. Foreign language anxiety and heritage students of Spanish: A quantitative study. Foreign Language Annals, v. 42, n. 1, pp. 112-137, 2009.

TORRES, J. The effects of task complexity on heritage and L2 Spanish development. The Canadian Modern Language Review, v. 74, n. 1, pp. 128-152, 2018.

TORRES, K. Heritage language learners' perception of taking Spanish language classes: Investigating perception of skill-specific anxieties, self-efficacies, and ethnic identity. 2011. 140 p. Thesis (Doctorate in Educational Psychology) - College of Education, Florida State University. Retrieved from https://diginole.lib.fsu.edu/islandora/object/fsu\%3A253942. Date of access: 25 Sept. 2019.

U.S. CENSUS BUREAU. 2012-2016 American Community Survey 5-Year Estimates. 2016. Retrieved from: http://factfinder2.census.gov. Date of access: 25 May 2018.

VALDÉS, G. Heritage language students: profiles and possibilities. In: PEYTON, J.K.; RANARD, D.A.; McGINNIS, S. (Eds.). Heritage languages in America: Preserving a natural resource. McHenry, IL: Center for Applied Linuistics e Delta Systems, 2001. pp. 37-77.

VALDÉS, G.; LOZANO, A.; GARCÍA-MOYA, R. (Eds.). Teaching Spanish to the Hispanic bilingual: Issues, aims, and methods. New York: Teachers College Press, 1981.

VENTURIN, B. "I don't fit in here and I don't fit in there:" Understanding the connections between L1 attrition and feelings of identity in 1.5 generation of Russian Australians. Heritage Language Journal, v. 16, n. 2, pp. 238-268, 2019. Retrieved from: https://www.heritagelanguages.org/. Date of access: 23 Sept. 2019.

VILLA, D. Theory, design, and content for a "grammar" class for native speakers of Spanish. In: COLOMBI, M.C.; ALARCÓN, F. (Eds.). La enseñanza del español a hispanohablantes: Praxis y teoría. Boston: Houghton Mifflin, 1997. pp. 93-102.

WONG, K. F.; XIAO, Y. Diversity and difference: Identity issues of Chinese heritage language 
194 | Gláucia Silva

learners from different backgrounds. Heritage Language Journal, v. 7, n. 2, pp. 314-348, 2010. Retrieved from: https://www.heritagelanguages.org/. Date of access: 13 Aug. 2013.

YANGUAS, I. A quantitative approach to investigating Spanish HL speakers' characteristics and motivation: A preliminary study. Hispania, v. 93, n. 4, pp. 650-670, 2010.

Recebido em: 29/09/19

Aceito em: 03/11/19 